\section{TARS-HT1 and TARS-HT2 Heat-tolerant Dry Bean Germplasm}

Timothy G. Porch ${ }^{1}$

USDA-ARS Tropical Agriculture Research Station, 2200 P.A. Campos Avenue, Suite 201, Mayaguez, PR 00680

James R. Smith

USDA-ARS, 141 Experiment Station Road, JWDSRC, Stoneville, MS 387760345

\section{James S. Beaver}

Department of Agro-Environmental Sciences, University of Puerto Rico, Recinto Universitario de Mayaguez, Call Box 9000, Mayaguez, PR 006819000

\section{Phillip D. Griffiths}

Department of Horticultural Sciences, New York State Agricultural Experiment Station, 630 West North Street, Geneva, NY 14456

\section{Craig H. Canaday}

Entomology and Plant Pathology Department, The University of Tennessee, 605 Airways Boulevard, Jackson, TN 38301

Additional index words. common bacterial blight, heat stress, high ambient temperature, Phaseolus vulgaris, Xanthomonas axonopodis

High average maximum daytime (greater than $30{ }^{\circ} \mathrm{C}$ ) and minimum nighttime (greater than $20^{\circ} \mathrm{C}$ ) temperatures can significantly affect common bean yields in the lowland (less than 650 masl) tropics (Singh et al., 2000). High-temperature stress results in excessive abortion of buds, flowers, and pods, and in the abortion of seed within the pod, resulting in the formation of small seedless common bean pods and dramatic yield reduction. TARS-HT1 and TARS-HT2 are heat-tolerant dark red and light red, respectively, kidney beans (Phaseolus vulgaris L.) with tolerance to hightemperature stress in both temperate and humid tropical environments. The lines were developed cooperatively by the USDA-ARS Tropical Agriculture Research Station (TARS), the University of Puerto Rico (UPR), Cornell University, and the University of Tennessee. TARS-HT2 is tolerant to high daytime temperature stress and moderate nighttime temperature stress, whereas TARS-HT1 is tolerant to high daytime and nighttime temperature stress.

\section{Origin}

TARS-HT1 (tested as 98059-6-2-1) and TARS-HT2 (tested as 98059-10-2-1) were

\footnotetext{
Received for publication 5 Mar. 2010. Accepted for publication 1 June 2010 .

Mention of trade names or commercial products in this article is solely for the purpose of providing specific information and does not imply recommendation or endorsement by the U.S. Department of Agriculture.

${ }^{1}$ To whom reprint requests should be addressed; e-mail timothy.porch@ars.usda.gov.
}

derived from a single cross between IJR (Indeterminate Jamaica Red) and 'Montcalm'. IJR is grown in the Caribbean but was collected in India (PI 163122, G 8088). IJR is a mottled light red kidney with a Type III growth habit and heat tolerance (Baiges et al., 1996; Miklas et al., 2000a). Montcalm is a dark red kidney cultivar with a Type I growth habit developed at Michigan State University from a single cross between GN No.1 and 'Dark Red Kidney' (Copeland and Erdmann, 1977). Montcalm has the SAP6 SCAR marker linked to a QTL for common bacterial blight (CBB) resistance; the $I$ gene, which provides resistance to Bean common mosaic virus (BCMV); and is resistant to halo blight and anthracnose.

Hybridizations were made and $F_{1}$ plants grown in a screen house at TARS in Mayaguez, PR, from Oct. to Dec. 1998 and from Jan. to Mar. 1999, respectively. Single $F_{2}$ plants were selected under high-temperature and humidity conditions in Aug. 1999 at the UPR Substation in Juana Diaz, PR, whereas single $F_{3}$ plants were selected in a nursery at Isabela, PR, in Feb. 2000. During the summer months (July through September) of 2000 in Mayaguez, $\mathrm{F}_{4}$ plants were grown in rigorous high-temperature greenhouse conditions with mean maximum and minimum temperatures of $39^{\circ} \mathrm{C}$ and $24^{\circ} \mathrm{C}$, respectively. Heat-tolerant $\mathrm{F}_{4: 5}$ lines, 98059-6-2-1 and 98059-10-2-1, were selected in this environment. Seed was bulked and increased at Isabela from Jan. to Mar. 2001. Preliminary yield tests were conducted at Juana Diaz from June to Aug. 2001 using $\mathrm{F}_{4: 6}$ seed, at which time both lines were selected for further testing.
TARS-HT1 (98059-6-2-1) and TARSHT2 (98059-10-2-1) were evaluated in the field under high-temperature and non-stress conditions in two distinct climatic zones (Table 1). High-temperature, temperate climatic zone, field trials were conducted at the University of Tennessee in Jackson, TN, in 2002 and 2004. High-temperature, subtropical climatic zone trials were conducted at the UPR Juana Diaz Substation during the warmer summer months in 2004 and 2008 . Drought stress was avoided in Tennessee and Puerto Rico through adequate lateral boom and drip irrigation, respectively, to supplement rainfall. Non-stress trials were conducted during the cooler winter months at the UPR Isabela Substation and at the TARS Station, both located in Isabela, in 2008 and 2009 , respectively, and were watered with overhead irrigation. Both lines were also evaluated in the greenhouse under moderate day and high nighttime temperature conditions in 2005 and 2007 at Cornell University in Geneva, NY. In 2005, they were evaluated in concurrent trials under stress and nonstress conditions, whereas in 2007 , they were evaluated under high-temperature conditions only. Yield and maturity data were collected in stress and non-stress trials. A randomized complete block design (RCBD) was used with five replications in the 2008 Isabela field trial. A RCBD with six or eight replications was used in the Jackson, TN, trials in 2002 and 2004, respectively, whereas three replications in a RCBD were used in the other trials. Least significant differences at $P \leq 0.05$ were used to compare means for seed yield.

TARS-HT1 and TARS-HT2 were tested for the presence of SCAR markers linked to QTL for CBB resistance and for BCMV resistance ( $I$ gene) using the SAP6 (Miklas et al., 2000b) and SW13 (Melotto et al., 1996) SCAR markers, respectively. In addition, both lines were tested for the presence of the $I$ gene by inoculating the plants in the greenhouse with the $N L 3$ strain of BCMV and recording the presence of the hypersensitive resistance response. Phenotypic testing for CBB resistance was completed through use of the multiple needle technique in the greenhouse (Zapata et al., 2007) using Xanthomonas axonopodis pv. phaseoli (Xap) strains 484a and 3353 and through natural infection in the field. At 7, 14, and $21 \mathrm{~d}$ after inoculation, leaves were scored for CBB on a 1 to 9 scale (1, no symptoms; 9 , complete infection of the leaf) (CIAT, 1987). A randomized complete block design was used with five replications in the CBB-inoculated greenhouse trial. Least significant differences at $P \leq$ 0.05 were used to compare means for $\mathrm{CBB}$ reaction.

\section{Description and Performance}

The performance of TARS-HT1 and TARS-HT2 under high-temperature conditions in the field was evaluated in Jackson, $\mathrm{TN}$, and in Juana Diaz, PR. Additional sources of stress were present in these field trials as noted (Table 2 ) resulting in multiple 
sources of stress affecting yield. TARS-HT1 and TARS-HT2 showed a significantly higher seed yield than Montcalm in the Juana Diaz (2004) stress trial (Table 2), whereas TARS-HT2 had a significantly higher seed yield than Montcalm in the 2002 heat stress trial in Jackson, TN, and a significantly higher yield than 'Redhawk' in the non-stress Isabela 2008 trial. Furthermore, TARS-HT2 yielded more than CELRK in 2004 in Jackson, TN, and had a significantly higher yield than TARS-HT1 in both years in Tennessee. The mechanisms for the yield advantage over the control cultivars under these high-temperature conditions were increased numbers of pods per plant and higher seed weight per plant (data not shown). Pod number was previously shown to be important in the genetic response to high-temperature stress (Porch et al., 2004). In addition, TARS-HT1 and TARS-HT2 showed a reduction in the symptoms characteristic of high-temperature stress such as excessive bud and flower abortion, development of small seedless pods, and pod deformation resulting from seed abortion or poor seed fill as compared with the control genotypes.

The Jackson, TN, 2002 trial was a lowfertility trial and resulted in lower yields as compared with the 2004 trial (Table 2). Rates of nitrogen $(\mathrm{N})$ fertilization in 2004 were 90 $\mathrm{kg} \mathrm{N} / \mathrm{ha}$ compared with $39 \mathrm{~kg} \cdot \mathrm{ha}^{-1}$ in 2002 , whereas phosphorus (P) fertilization was $14 \mathrm{~kg} \mathrm{P} / \mathrm{ha}$ in 2004 and $0 \mathrm{~kg} \cdot \mathrm{ha}^{-1}$ in 2002. Furthermore, 2002 was slightly hotter and received less rain than 2004: $4 \mathrm{~cm}$ water (rain + irrigation) during flowering and pod set in 2002 versus $10 \mathrm{~cm}$ water in 2004. The relatively poor yields of the 2004 Juana Diaz trial, compared with those of 2008, were likely caused by an increased prevalence of southern blight caused by Sclerotium rolfsii Sacc. and higher temperature conditions. Seed yields of both TARS-HT2 and 'Montcalm' were considerably reduced compared with the yields obtained in the other trials.

The moderate day and high nighttime temperature conditions in the 2005 and 2007 greenhouse trials at Geneva were particularly stressful as a result of the high night temperatures used. Common bean has been shown to be especially susceptible to high night temperatures (Kigel et al., 1991; Konsens et al., 1991). TARS-HT1 experienced an average of $0 \%$ decrease in pod number and a $22 \%$ decrease in seed number in the high nighttime temperature conditions as compared with the non-stress treatment and was the most heat-tolerant of the 24 breeding lines tested in the trial (data not shown). The heatsusceptible controls, ICA Pijao and 'Hystyle', showed a $100 \%$ and $45 \%$ average reduction in pod number and a $100 \%$ and $74 \%$ reduction in seed number, respectively (data not shown). In 2007 , under the $32 / 27^{\circ} \mathrm{C}$ temperature conditions, TARS-HT1 produced a mean of 13 pods and $7.4 \mathrm{~g}$ of seed per plant. The control, 'Hystyle', produced a mean of one pod and $0.3 \mathrm{~g}$ of seed weight. In both greenhouse trials, TARS-HT2 showed a susceptible response and did not produce pods or seeds, whereas TARS-HT1 showed tolerance to high nighttime temperature stress (data not shown).

TARS-HT1 and TARS-HT2 showed moderate susceptibility to common bacterial blight under natural infection in Isabela, whereas they were both more resistant than 'Redhawk' or USDK CBB-15 (Table 3). In addition, TARS-HT1 showed more resistance than 'Redhawk' and TARS-HT2 to inoculation with common bacterial blight in the greenhouse in Mayaguez using Xap strains 484A and 3353 (Table 4). Neither carried the SAP6 marker. In the greenhouse, a hypersensitive response to the $N L 3$ strain of Bean common mosaic necrotic virus indicated segregation for the $I$ gene in TARSHT1 and absence of the I gene in TARS-HT2.
These results for the presence of the $I$ gene were confirmed with the SW13 SCAR marker.

TARS-HT1 and TARS-HT2 are $\mathrm{F}_{4}$-derived determinate bush beans with Type I growth habits. TARS-HT1 matures at $71 \mathrm{~d}$ after planting in Puerto Rico and $92 \mathrm{~d}$ in Tennessee and TARS-HT2 matures at $72 \mathrm{~d}$ after planting in Puerto Rico and $106 \mathrm{~d}$ in Tennessee. Both TARS-HT1 and TARS-HT2 have kidneyshaped seeds with good plant architecture and good seed quality (Table 3 ) that is commercially acceptable in Puerto Rico and the United States. Under non-stress conditions, TARS-HT1 averages $48 \mathrm{~g} / 100$ seed and has a dark red seedcoat color, and TARSHT2 averages $50 \mathrm{~g} / 100$ seed and has a light red seedcoat color.

Table 1. Ambient air temperatures in non-stress and stress greenhouse and field trials.

\begin{tabular}{llllcr}
\hline & & & & \multicolumn{2}{c}{ Avg daily temperatures $\left(^{\circ} \mathrm{C}\right)$} \\
\cline { 3 - 6 } Trial & Yr & Treatment & Location & Maximum & Minimum \\
\hline Jackson, TN & 2002 & Stress & Field & 37 & 18 \\
Jackson, TN & 2004 & Stress & Field & 35 & 16 \\
Juana Diaz, PR & 2004 & Stress & Field & 33 & 24 \\
Geneva, NY & 2005 & Stress & Greenhouse & 32 & 27 \\
Geneva, NY & 2005 & Non-stress & Greenhouse & 24 & 20 \\
Geneva, NY & 2007 & Stress & Greenhouse & 32 & 27 \\
Juana Diaz, PR & 2008 & Stress & Field & 32 & 19 \\
Isabela, PR & 2008 & Non-stress & Field & 26 & 19 \\
Isabela, PR & 2009 & Non-stress & Field & 27 & \\
\hline
\end{tabular}

${ }^{\mathrm{z}}$ Average daily temperatures during reproductive development, from flowering through pod fill.

Table 2. Mean seed yield $\left(\mathrm{kg} \cdot \mathrm{ha}^{-1}\right)$ under stress in Jackson, TN, in 2002 and 2004, under stress in Juana Diaz, PR, in 2004 and 2008, and under non-stress conditions in 2008 and 2009 in Isabela, PR.

\begin{tabular}{|c|c|c|c|c|c|c|}
\hline \multirow[b]{5}{*}{ Genotyne } & \multicolumn{4}{|c|}{ Stress $^{\mathrm{z}}$} & & \\
\hline & $\mathrm{HT}, \mathrm{LF}$ & HT & $\mathrm{HT}, \mathrm{SB}$ & $\mathrm{HT}, \mathrm{SB}$ & \multirow{2}{*}{\multicolumn{2}{|c|}{ Non-stress }} \\
\hline & \multirow{2}{*}{$\begin{array}{c}\text { Jackson, } \\
\text { TN }\end{array}$} & \multirow{2}{*}{$\begin{array}{c}\text { Jackson, } \\
\text { TN }\end{array}$} & \multirow{2}{*}{$\begin{array}{c}\text { Juana Diaz, } \\
\text { PR }\end{array}$} & \multirow{2}{*}{$\begin{array}{c}\text { Juana Diaz, } \\
\text { PR }\end{array}$} & & \\
\hline & & & & & Isabela, PR & Isabela, PR \\
\hline & 2002 & 2004 & 2004 & 2008 & 2008 & 2009 \\
\hline$\overline{\text { TARS-HT1 (DRK) }}$ & 681 & 1518 & 813 & 1032 & 1467 & 1097 \\
\hline TARS-HT2 (LRK) & 1065 & 2052 & 534 & 1320 & 1586 & 1126 \\
\hline CELRK (LRK) & 1052 & 1680 & NT & NT & NT & NT \\
\hline Montcalm (DRK) & 576 & 1318 & 138 & 592 & 1266 & 878 \\
\hline Redhawk (DRK) & $\mathrm{NT}^{\mathrm{x}}$ & NT & NT & 656 & 1170 & 710 \\
\hline Mean & 844 & 1642 & 495 & 900 & 1372 & 953 \\
\hline Least significant & 147 & 207 & 321 & 788 & 385 & 536 \\
\hline
\end{tabular}

difference (0.05)

${ }^{\mathrm{z}}$ Stress conditions in field trials: $\mathrm{HT}=$ high temperature; $\mathrm{SB}=$ Southern blight caused by Sclerotium rolfsii;

$\mathrm{LF}=$ low fertility

${ }^{\mathrm{y}}$ Seed type: $\mathrm{DRK}=$ dark red kidney; LRK $=$ light red kidney.

${ }^{\mathrm{x}} \mathrm{NT}=$ not tested.

Table 3. Quality characteristics and common bacterial blight reaction of kidney bean lines under non-stress field conditions in Isabela, PR, Oct. 2008.

\begin{tabular}{lccc}
\hline Line & $\begin{array}{c}\text { Mean common } \\
\text { blight score }\end{array}$ & $\begin{array}{c}\text { Mean phenotypic } \\
\text { score }^{\mathrm{y}}\end{array}$ & $\begin{array}{c}\text { Mean seed } \\
\text { quality score }^{\mathrm{x}}\end{array}$ \\
\hline TARS-HT1 (DRK) & 5.2 & 5.2 & 3.2 \\
TARS-HT2 (LRK) & 5.2 & 6.4 & 3.2 \\
Montcalm (DRK) & 5.0 & 5.4 & 3.0 \\
Redhawk (DRK) & 7.0 & 5.8 & 3.4 \\
USDK CBB-15 (DRK) & 7.8 & 6.8 & 5.0 \\
Mean & 6.0 & 5.9 & 3.6 \\
Least significant difference (0.05) & 1.1 & 0.8 & 0.8 \\
\hline
\end{tabular}

${ }^{\mathrm{z}}$ Rated on a scale from 1 to 9 in which $1=$ no symptoms and $9=$ very severe symptoms of common bacterial blight caused by natural infection.

${ }^{y}$ Rated on a scale from 1 to 9 in which $1=$ erect plants with good pod set and $9=$ undesirable plant type ${ }^{x}$ Rated on a scale from 1 to 9 in which $1=$ excellent commercial seed quality and $9=$ non-commercial seed quality.

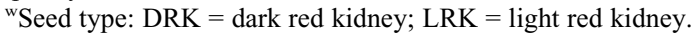


Table 4. Common bacterial blight (Xanthomonas axonopodis pv. phaseoli) disease progression on red kidney cultivars, germplasm, and VAX 6-resistant control inoculated in the greenhouse in Mayaguez, PR.

\begin{tabular}{|c|c|c|c|c|c|c|}
\hline \multirow[b]{3}{*}{ Genotype } & \multicolumn{2}{|c|}{ Day 7} & \multicolumn{2}{|c|}{ Day 14} & \multicolumn{2}{|c|}{ Day 21} \\
\hline & \multicolumn{6}{|c|}{ Common bacterial blight strain } \\
\hline & 3353 & 484A & 3353 & $484 \mathrm{~A}$ & 3353 & $484 \mathrm{~A}$ \\
\hline$\overline{\text { TARS-HT1 (DRK) }{ }^{z}}$ & $2.8^{\mathrm{y}}$ & 2.0 & 5.2 & 3.0 & 7.2 & 4.3 \\
\hline TARS-HT2 (LRK) & 4.4 & 2.5 & 7.0 & 4.5 & 9.0 & 7.3 \\
\hline Montcalm (DRK) & 2.8 & 2.0 & 6.2 & 2.8 & 8.0 & 3.8 \\
\hline Redhawk (DRK) & 3.8 & 2.4 & 8.0 & 4.4 & 9.0 & 7.0 \\
\hline USDK CBB-15 (DRK) & 2.2 & 2.0 & 4.2 & 2.4 & 7.4 & 3.8 \\
\hline VAX 6 (small red) & 1.5 & 1.5 & 2.3 & 1.5 & 3.5 & 2.0 \\
\hline Mean & 2.9 & 2.0 & 5.5 & 3.1 & 7.4 & 4.7 \\
\hline $\begin{array}{l}\text { Least significant } \\
\text { difference }(0.05)\end{array}$ & 0.7 & 0.5 & 0.9 & 0.8 & 0.9 & 1.1 \\
\hline
\end{tabular}

${ }^{\mathrm{z}}$ Seed type: DRK $=$ dark red kidney; LRK $=$ light red kidney.

${ }^{\mathrm{y}}$ Rated on a scale (CIAT, 1987) from 1 to 9 in which $1=$ no symptoms and $9=$ very severe symptoms of common bacterial blight.

\section{Availability}

Small amounts of TARS-HT1 and TARSHT2 are available as F $_{4}$-derived germplasm lines from the corresponding author. This germplasm release is publicly available.

\section{Literature Cited}

Baiges, S., J.S. Beaver, P.N. Miklas, and J.C. Rosas. 1996. Evaluation and selection of dry beans for heat tolerance. Ann. Rep. of the Bean Improv. Coop. 39:88-89.
Konsens, I., M. Ofir, and J. Kigel. 1991. The effect of temperature on the production and abscission of flowers and pods in snap bean (Phaseolus vulgaris L.). Ann. Bot. (Lond.) 67:391-399. Melotto, M., L. Afanador, and J.D. Kelly. 1996. Development of a SCAR marker linked to the $I$ gene in common bean. Genome 39:12161219.

Miklas, P.N., R. Hannan, J.R. Smith, J.S. Beaver, R. Riley, and S. Antonius. 2000a. Transferring heat tolerance and indeterminacy from indeterminate Jamaica red (PI 163122) to kidney bean. Annu. Rep. Bean Improv. Coop. 43:68-69.

Miklas, P.N., V. Stone, M.J. Daly, J.R. Stavely, J.R. Steadman, M.J. Bassett, R. Delorme, and J.S. Beaver. 2000b. Bacterial, fungal and viral disease resistance loci mapped in a recombinant inbred common bean population ('Dorado'/ XAN 176). J. Amer. Soc. Hort. Sci. 125:476481.

Porch, T.G., M.H. Dickson, M.C. Long, D.R. Viands, and M. Jahn. 2004. General Combining ability effects for reproductive heat tolerance in snap bean. J. Agr. Univ. Puerto Rico 88:161164.

Singh, S.P., F.J. Morales, P.N. Miklas, and H. Terán. 2000. Selection for bean golden mosaic resistance in intra- and interracial bean population. Crop Sci. 40:1565-1572.

Zapata, M., J. Beaver, and T. Porch. 2007. Foliage, pod and internal seed infection of selected common bean lines when inoculated with two strains of Xanthomonas axonopodis pv. phaseoli Ann. Rep. Bean Improv. Coop. 50:117118. 